\title{
V 字管屈曲部滞溜液の気流によるスラッギング現象に関する研究*
}

\author{
入倉 基樹 ${ }^{* 1}$, 細川 茂雄 ${ }^{* 2}$, 冨山 明男 ${ }^{* 2}$
}

\author{
Onset of Slugging of Stagnant Liquid at a V-Shaped Elbow in a Pipeline \\ Motoki IRIKURA*1, Shigeo HOSOKAWA and Akio TOMIYAMA \\ ${ }^{* 1}$ Graduate School of Engineering, Kobe University, \\ 1-1 Rokkodai, Nada-ku, Kobe-shi, Hyogo, 657-8501 Japan
}

\begin{abstract}
Slugging of a stagnant liquid at a V-shaped elbow in a hilly-terrain pipeline is experimentally investigated to obtain information on flow regime and critical conditions of the slugging. According to flow observation using a high-speed camera, the flow is classified into seven flow regimes, i.e. static puddle, wavy puddle, periodic slug flow, periodic semi-slug flow, aperiodic semi-slug flow, film flow and pebble flow. The onset of the slugging is well predicted not by the Mishima-Ishii's model, but by the Wallis parameter used for flooding in a pipe. This means that the slugging at the V-shaped elbow is similar to the flooding caused by interfacial shear stress. An empirical correlation based on a modified Wallis parameter is proposed to represent the effects of inclination angle, pipe diameter and fluid properties on the onset of slugging.
\end{abstract}

Key Words : Slugging, V-Shaped Elbow, Pipeline, Flow Regime, Flooding, Kelvin-Helmholtz Instability

\section{1. 緒言}

石油や天然ガスを輸送するパイプラインは，地形に沿って敷設されるため，水平管，鉛直管，傾斜上昇管およ び傾斜下降管が様々なパターンで繋ぎ合わされて構成されている. また, 各種プラントにおける配管も水平管, 鉛直管などが複雑に組み合わされている．このような複雑な配管系には，配管の高さが極小值をとる凹部が存在 することが多い. パイプラインでしばしば見られる傾斜上昇管および傾斜下降管の繋ぎ目にあるV 字部はその典 型である.このような $\mathrm{V}$ 字部に石油等の液体が滞溜すると, プラントの起動/停止時の流動抵抗が増加したり, 低気相流量時に圧力変動が大きくなる場合がある ${ }^{(1)}$.これは，V 字部に滞溜した液体のスラッギングに起因する ため ${ }^{(2)}$ ，配管の設計・改良もしくはプラント運転手順の決定においてはV 字部おけるスラッギング発生条件を評 価する必要がある.

これまでに，水平管，鉛直管または傾斜管等の直管内を流動する気液二相流の研究は数多く行われており，水 平直管におけるスラグ発生条件に関してもいくつかの式が提案されている(3)-(5). V 字部を含む丘谷形状配管系に おける気液二相流は, 主に石油輸送分野で研究がなされてきた。これらの研究では, 輸送効率は高いが流動振動 が生じるスラグ流を主な対象とし，スラグ速度，スラグ長さなどの基礎データ(6),(7)が報告されるとともに，管路 に沿ったスラグの成長・衰退モデル(8)も提案されている。この結果, 近年では管路内スラグ流の過渡状態の数值 計算 ${ }^{(8)-(11)}$ も行われているが，スラグ発生機構，発生条件に関する研究は少なく，計算におけるスラグ発生条件や 初期条件の設定方法に関する知見が極めて少なく, 数值計算の検証データも限られている. 特に, V 字部におけ る滞溜流体のスラッギング現象は, 配管の過渡状態解析において重要であるにも関わらず Fitremann ${ }^{(12)}$ 以外に研 究例が見当たらない. Fitremann ${ }^{(12)}$ は，屈曲部に滞留した液のスラッギングが，気相流速の滞溜液部での加速に伴 う気液界面上昇により管が閉塞されて生じると考え, 液体が管を閉塞する気相体積流束と滞溜液体積の関係式を 提案している. 彼らは実験を実施し, 提案式と比較しているが, 滞溜液体積が少ない条件では実験と提案式の差 が大きい．また，屈曲部の流動状態や流動様式遷移，管傾斜角や管径，流体物性の影響に関する資料は提供され

* 原稿受付 2012 年 2 月 27 日

*1 神戸大学大学院工学研究科（广 $657-8501$ 兵庫県神戸市灘区六甲台町 1-1）

*2 正員, 神戸大学大学院工学研究科

E-mail: tomiyama@mech.kobe-u.ac.jp 
ていない.

本研究では, 緩傾斜下降管から緩傾斜上昇管に移る V 字部に着目し，V字管底部に滞溜した液体がその上部を 流れる気体によりスラッギングを開始寸る流動条件を調べた。この際，滞溜液相体積と気相体積流束をパラメー タとして滞溜液の流動様式を観察するとともに，スラッギングが発生する臨界気相体積流束を測定した。また， スラグ発生条件に管傾斜角，管径，液物性が及ぼす影響を調べた。

\section{2. 主な記号}

$\begin{array}{llr}B o: & \text { ボンド数 } & \\ D: & \text { 管内径 } & {[\mathrm{m}]} \\ g: & \text { 重力加速度 } & {\left[\mathrm{m} / \mathrm{s}^{2}\right]} \\ h_{G}: & \text { 気液界面と上壁の距離 } & {[\mathrm{m}]} \\ J: & \text { 体積流束 } & {[\mathrm{m} / \mathrm{s}]} \\ J^{*}: & \text { Wallis パラメータ } & \\ Q_{L}: & \text { 滞溜液体積 } & {\left[\mathrm{m}^{3}\right]} \\ Q_{L \text { max }}: & \text { V 字部における最大滞溜液体積 } & {\left[\mathrm{m}^{3}\right]} \\ V: & \text { 速度 } & {[\mathrm{m} / \mathrm{s}]} \\ \Delta P: & \text { V 字部での圧力低下量 } & {[\mathrm{Pa}]} \\ \mu: & \text { 粘性係数 } & {[\mathrm{Pa} \mathrm{s}]} \\ \theta: & \text { 配管傾斜角 } & {[\mathrm{deg}]} \\ \rho: & \text { 密度 } & {\left[\mathrm{kg} / \mathrm{m}^{3}\right]} \\ \sigma: & \text { 表面張力 } & {\left[\mathrm{N} / \mathrm{m}^{2}\right]}\end{array}$

\section{添え字}

$G: \quad$ 気相

$L: \quad$ 液相

\section{3. 実験装置および方法}

実験装置の概略を図 1 に，試験部の拡大図を図 2 にそれぞれ示す.

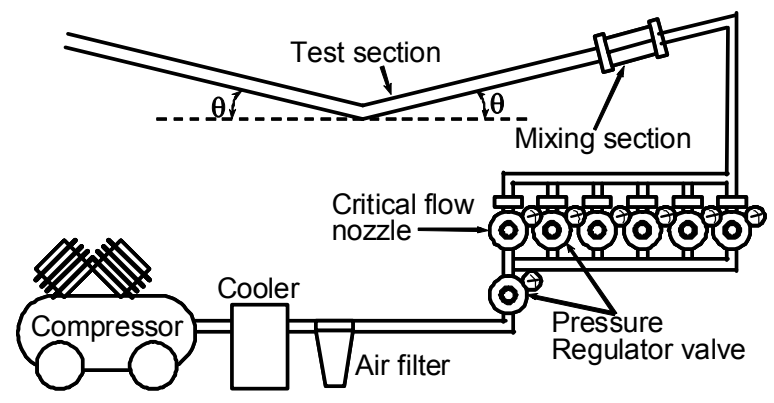

Fig. 1 Experimental apparatus

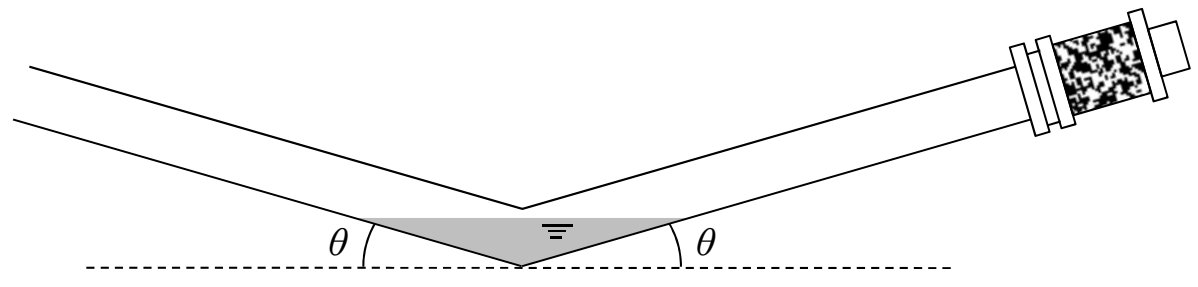

Fig. 2 Schematic of test section 
装置は主に気相供給部および試験部からなり，流体には常温常圧の空気および水またはグリセリン水溶液を用 いた. 気相供給部では，オイルフリーコンプレッサ（Hitachi，7.50U-7V6）から吐出した空気が臨界ノズルを通過 後, 試験部へと流入する。なお，臨界ノズル上流圧力と空気流量の関係は予め乾式ガスメータ（品川精器製）を 用いて検定している．試験部はアクリル製透明円管で構成され，傾斜角の等しい下降管および上昇管および両者 を接続する V 字部で構成されている。 V 字接合部の曲率半径は $0 \mathrm{~m}$ である. 実験は, 管内径 $D$ が $2.0,3.0,4.0 \mathrm{x}$ $10^{-2} \mathrm{~m}$ の 3 条件, 傾斜角度 $\theta$ 王 $3^{\circ}, 5^{\circ}, 7^{\circ}$ の 3 条件で実施した。 また, V 字部までに流れが発達するよう, 試 験部入口に整流器を設置した. 入口部から V 字部までの距離は，V 字部手前で気相が完全発達流となるように， $100 \mathrm{D}$ 以上とした．なお，熱線流速計（カノマックス社製）による流速分布測定により V 字部に達する前に完全 発達流となっていることを確認している，V字部から出口部までの距離は，発生したスラグにより液相が出口部 から流出しないように十分な長さ（2.5 m 以上）とした.

液相にはフィルタを通した水道水およびグリセリン水溶液を用いた. グリセリン水溶液の物性值を表 1 に示寸. $\mathrm{V}$ 字部に所定の体積の液体を滞溜させた後, 気相体積流束 $J_{G} を 0 \sim 8.0 \mathrm{~m} / \mathrm{s}$ の範囲で $1.0 \mathrm{~m} / \mathrm{s}$ 刻みで变化させ, 各 $J_{G}$ において流れが安定した後の流動状態を目視観察するとともに高速度カメラ（フォトロン製 Fast cam rabbit 3

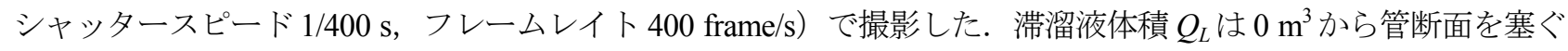
体積 $\left(Q_{\text {Lmax }}\right)$ まで $5.0 \times 10^{-6} \mathrm{~m}^{3}$ 刻みで変化させた. ただし, 流動状態の変化が激しい遷移領域では, 気相流束を $0.1 \mathrm{~m} / \mathrm{s}$, 液相体積を $1.0 \times 10^{-6} \mathrm{~m}^{3}$ 刻みで変化させた. 同様に V 字部に所定の体積の液体を滞溜させた後, 気相体 積流束 $J_{G}$ を $0 \mathrm{~m} / \mathrm{s}$ から極めてゆっくりと上昇させていき, 液体スラグが始めて発生した時点での $J_{G}$ をラッギン グ開始点として記録した．また， V 字部屈曲点に設置した二線電極プローブ(13)により，液体スラグ発生直前の液 位も測定した．なお，V 字部への液相注入は, 所定量の液体を溜めた注射器にテフロンチューブを接続し, 流路 出口からチューブを $\mathrm{V}$ 字部まで挿入して管内壁を濡らさないように注意して行った.

Table1 Physical properties of glycerin

\begin{tabular}{|l|c|c|c|}
\hline & Density $\rho_{L}\left(\mathrm{~kg} / \mathrm{m}^{3}\right)$ & Surface tension $\sigma\left(\times 10^{-3} \mathrm{~N} / \mathrm{m}\right)$ & Viscosity $\mu_{L}\left(\times 10^{-3} \mathrm{~Pa} \mathrm{~s}\right)$ \\
\hline Glycerol water solution $20 \%$ & 1039 & 62.9 & 1.95 \\
\hline Glycerol water solution 40\% & 1081 & 61.5 & 5.20 \\
\hline
\end{tabular}

\section{4. 流動様式}

$\mathrm{V}$ 字部滞溜液のスラッギング開始点の流動様式全体における位置づけを明確化するため，流れを観察した．観 察された流動様式は, 静的液溜, 波状液溜, 周期性スラグ, 周期性セミスラグ, 無周期性セミスラグ, 上昇ペブ ル，上昇液膜の 7 種類に分類できる. 気相体積流束および滞溜液体積の変化と流動様式遷移の概略を流れの画像 とともに図 3 に示寸. また, 図 4 に管径 $D=2.0 \times 10^{-2} \mathrm{~m}$, 傾斜角 $\theta=3^{\circ}$ における流動様式線図を示す. 図中の線 はスラッギング開始条件を示している.

低 $J_{G}$ では, 滞溜液は気相が流れていない場合と同様に “静的液溜” (図 3(a)）の状態にある. $J_{G}$ が増加すると, まず V 字部において気相流路断面積が低下寸るため気相速度が増加し圧力が低下寸る，いわゆる「ベンチュリー 効果」によって, $\mathrm{V}$ 字部中心で液面の上昇が生じる．静的液溜は， $Q_{L}$ が小さいほじ，高い $J_{G}$ まで見られる．こ れは， $Q_{L}$ が小さいほど V 字部における気相流路断面積が大きく, 気相速度が低いためである.ささらに $J_{G}$ を増加 させると, 図3(b)に示寸ように気液界面に波立ちや摇れが発生する “波状液溜” の状態になる。 $Q_{L}$ が小さいほど この流動様式が見られる $J_{G}$ の範囲が広い. $J_{G}$ 増加に伴い, 高 $Q_{L}$ では静的液溜においてベルヌーイ効果による液 面上昇が大きくなり，低 $Q_{L}$ では波状液溜の波の振幅が大きくなり，最終的に液が管上壁に接して液体スラグが発 生する.この液体スラグが発生する最低気相流束をスラッギング開始点（スラッギングが発生する臨界気相体積 流束）とする．液体スラグ発生後は，流路閉塞に伴う圧力の上昇により液体スラグが下流側傾斜管を上昇しなが ら重力により崩壊し, 再び $\mathrm{V}$ 字部最下点に向かって逆流, 滞溜し, 液体スラグの形成・消滅を繰り返す. 低 $J_{G}$ では, 液体スラグの発生・崩壊が周期的に生じ，これを周期性スラグ (図 3(c)）と呼ぶ. $J_{G}$ が高くなると, 液体 スラグの上部が完全には管上壁に接触せず，気相流路が閉塞されていないセミスラグが周期的に発生・崩壊する 周期性セミスラグとなる (図 3(d)) . $J_{G}$ がさらに高くなると周期性が失われ無周期性セミスラグ (図 3(e)）に遷移 
する.さらに高い $J_{G}$ では液相に働く重力よりも気液界面での抗力が大きくなり, 液体は V 字部に逆流すること なく下流へ流される（図 3(g) 上昇液膜). 傾斜角が小さく液体体積が小さい場合には, 液膜が破断して分裂し, ペブル状の液滴が鉛管底部壁面に沿って下流に流れる（図3(f) 上昇ペブル）。 なお，傾斜角，管径が異なっても 流動様式線図に大きな差異は見られないが，上昇ペプルは傾斜角 $\theta=30$ でのみ観察された. 以上よりスラッギング 開始点は，ほぼ静的液溜または波状液溜と周期性スラグの遷移点に対応寸るが， $Q_{L}$ が低い領域ではスラッギング 開始点で波状液溜から周期性セミスラグへ直接遷移寸る，セミスラグでは気相流路が完全に閉塞されていないた め, 工業上主に問題となる圧力変動は小さく重要性が低いため, 以下では周期性スラグへの遷移に対応するスラ ッギング開始点を考察対象とする.

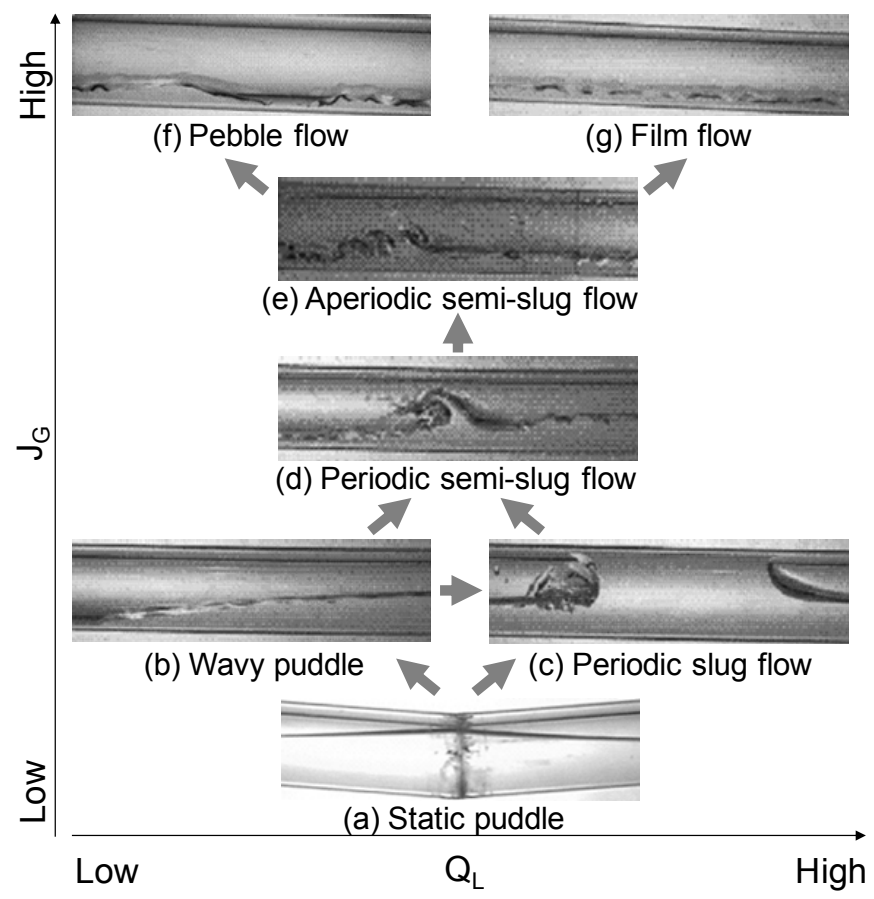

Fig. 3 Flow patterns and flow pattern transitions in the V-shaped portion

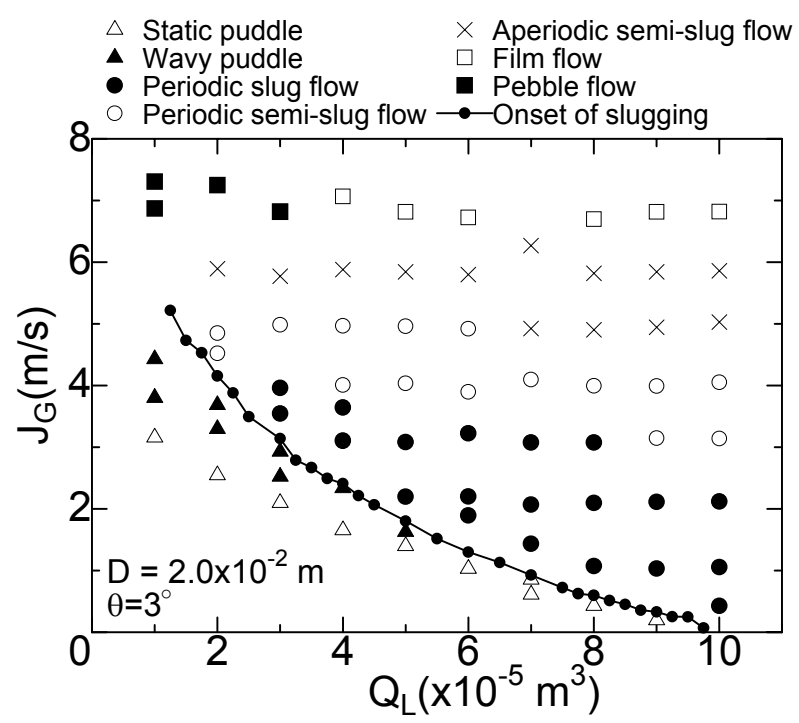

Fig. 4 Flow pattern map $\left(D=2.0 \times 10^{-2} \mathrm{~m}, \quad \theta=3^{\circ}\right)$ 


\section{$5 \cdot 1$ 支配パラメータの検討}

\section{5. スラッギング開始条件}

水平管におけるスラグ発生条件としては, 次式で表される Kelvin-Helmholtz $(\mathrm{K}-\mathrm{H})$ 不安定理論に基づく Mishima-Ishii の式 ${ }^{(5)}$ が広く用いられている.

$$
V_{G}-V_{L} \geq 0.487 \sqrt{\frac{\rho_{L} g h_{G}}{\rho_{G}}}
$$

ここで, $V$ は速度, $\rho$ は密度, $g$ は重力加速度, $h_{G}$ はスラグ発生直前の気相流路の高さ (気液界面と管上壁の距離) を, 添え字 $L$ および $G$ はそれぞれ液相および気相を表す. 本体系では液相が滞溜しているため $V_{L}=0 \mathrm{~m} / \mathrm{s}$ となる. 式(1)の本体系への適用性を検討寸るため, $D=2.0 \times 10^{-2} \mathrm{~m}$ の水一空気系実験における $V_{G}^{2}$ と $h_{G}$ の関係を式(1) $\left(V_{G}{ }^{2}\right.$ $\left.=1.90 h_{G}\right)$ とともに図 5 に示寸．なお， $V_{G}$ は二線電極プローブにより測定した V 字接合部における液位から算出 した.

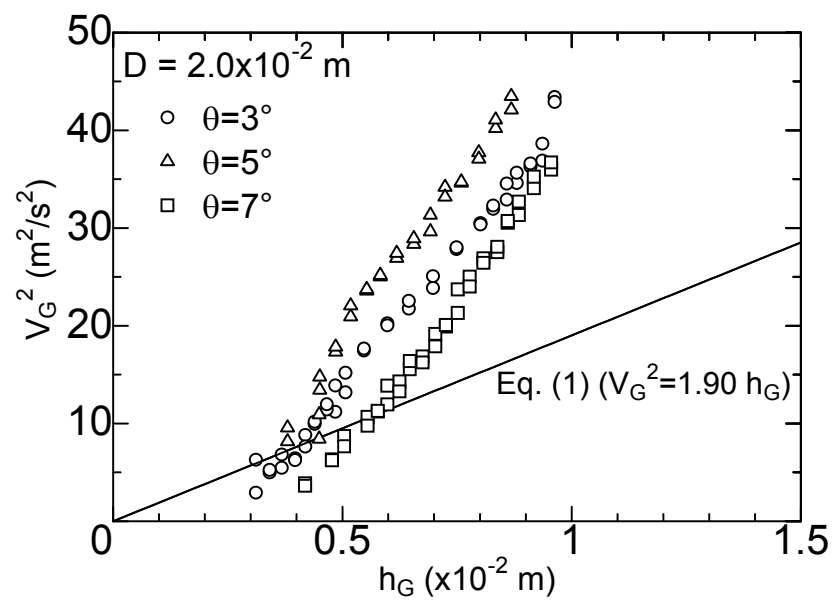

Fig. 5 Comparison of measured onset of slugging with Mishima-Ishii's model

$V_{G}^{2}$ と $h_{G}$ の測定結果は概ね線形関係にあるが，式(1)と異なり原点を通らず，傾きも大きい． $h_{G}>0.6 \times 10^{-2} \mathrm{~m}$ の 領域では式(1)よりも高い $V_{G}$ までスラッギングが生じていない. これは, Mishima-Ishii の式の前提となっている 無限長の水平管路では波は管路に沿って成長できるが，本体系のように流動軸方向に短い領域に限定された流れ

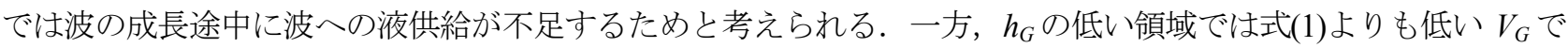
スラッギングが発生している. 低 $h_{G}$ は滞溜液が満水に近い状態に対応しており，このような条件ではメニスカス 効果によって気相流路断面積が極端に小さくなり，低 $J_{G}$ でも流路面積低下に伴う加速が大きく, $\mathrm{V}$ 字部での圧力 が低下寸る．このため，V 字部で夜体が引き上げられて気相流路が閉塞しスラッギングが生じたと考えられる. 以上のように，本体系は波の発達に十分な距離が無いこと，および加速損失による圧力低下が原因と考えられる スラッギング発生が含まれることが，式(1)でスラグ発生を評価できない理由といえる.

傾斜角が小さいことから位置ヘッドを無視すると, $\mathrm{V}$ 字部での圧力低下量 $\Delta P$ はベルヌーイの式から次式で表せ る.

$$
\Delta P=\frac{\rho_{G}}{2}\left(V_{G}^{2}-J_{G}^{2}\right)
$$

この $\mathrm{V}$ 字部での圧力低下により液相が吸い上げられ液位が $h_{G}$ だけ上昇した時にスラグが発生すると考えると， スラッギング開始点は次式で表せる.

$$
\Delta P=\frac{\rho_{G}}{2}\left(V_{G}{ }^{2}-J_{G}{ }^{2}\right)=\rho_{L} g h_{G}
$$

図 6 に $\Delta P$ と $h_{G}$ の関係を式(3)とともに示す. 
$h_{G}$ が大きい領域で $\Delta P$ は $h_{G}$ と線形関係があり, $\theta=3^{\circ}, 5^{\circ}$ に関しては原点を通る直線で近似できる. しかし,$\Delta P$ の実測值は式(3)の $20 \%$ 程度しかなく, $\theta=3^{\circ}, 5^{\circ}$ では $h_{G} \cong 5 \times 10^{-3} \mathrm{~m}$ で $\Delta P$ の $h_{G}$ 依存性が変化している. また, $\theta=7^{\circ}$ でも $\Delta P$ は $h_{G}$ の増加とともに直線的に増加するが，その直線は原点を通らない. さらに, $\Delta P$ の $\theta$ 依存性は単調で

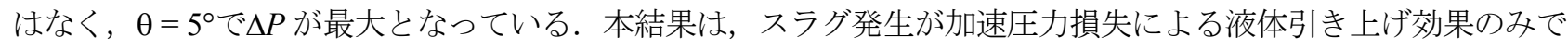
は説明できないことを示している.

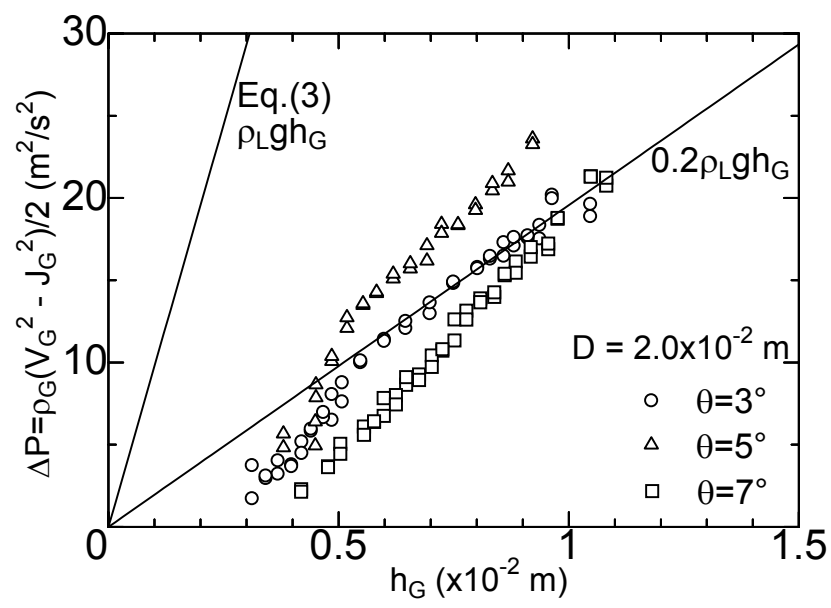

Fig. 6 Relationship between $\Delta P$ and $h_{G}$

スラッギング開始時の高速度カメラ映像から，V 字部では気相速度の増加に伴い液相に作用する界面せん断力 が強くなり, ある気相流速において界面が不安定になると一気に液体が流動化してスラグが発生することが示唆 される．この現象は，鉛直管を対象に数多く研究されてきたフラッディングと類似している．フラッディングは Wallis パラメータ (14)で整理できることが知られている. そこで, 次式で定義される Wallis パラメータと液相体積 $Q_{L}$ を満水の液相体積 $Q_{L \text { max }}$ で割った無次元液相体積 $Q_{L}{ }^{*}$ の関係を図 7 に示寸.

$$
\left(J_{G}^{*}\right)^{1 / 2}=\sqrt{\frac{J_{G}}{\sqrt{g D}}}
$$

$J_{G}{ }^{1} 1$ は $Q_{L}{ }^{*}$ 増加に従いほぼ直線的に減少しており, 傾斜角 $\theta$ よるデータのぼらつきも小さい. すなわち, $\mathrm{V}$ 字 部における滞溜液のスラッギング開始点は，フラッディングと同様な界面せん断応力に起因する界面不安定に伴 う流動化と捉えられる. なお, 本現象は液相の流動が殆どない状態で界面せん断応力が主因となり生じる現象で あるため, 界面せん断応力モデルの検証用データとして今後本データを有効活用できると考える.

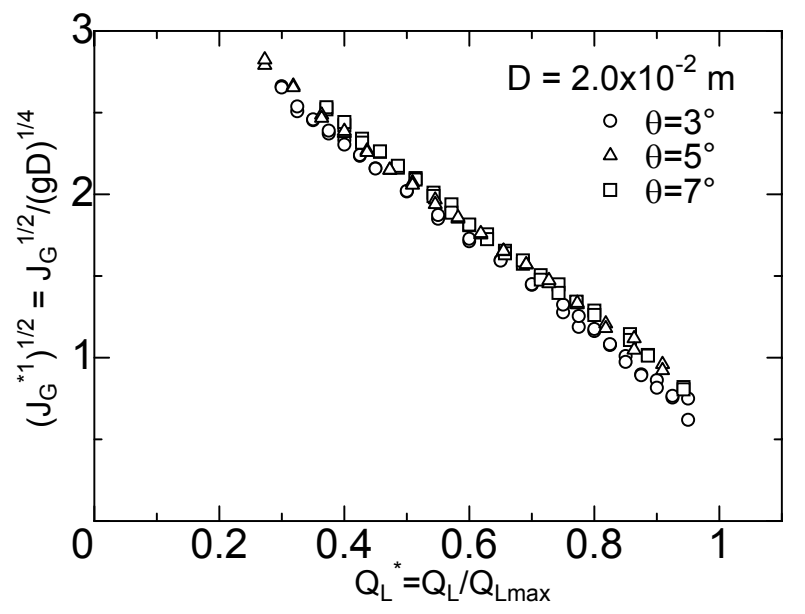

Fig. 7 Relationship between $J_{G}{ }^{1}$ and $Q_{L}{ }^{*}$ 


\section{$5 \cdot 2$ Wallis パラメータに基づく実験相関式}

前節においてV 字部におけるスラッギング開始点が Wallis パラメータ $J_{G}{ }^{* 1}$ と無次元液相体積 $Q_{L}{ }^{*}$ により良好に 整理できる可能性を示した. 本節では, Wallis パラメータと無次元液相体積 $Q_{L}{ }^{*}$ の関係に及ぼす種々のパラメータ の影響を調べるとともに，その影響を加味した実験相関式を作成する.

図 7 において傾斜角 $\theta$ に対するデータのばらつきは比較的少ないが，V字部に滞溜した液相が V 字部接合部に 戻る方向に働く重力 $g \sin \theta$ は界面の安定化に寄与寸ると考えられる. そこで, $\theta$ に対するデータのばらつきが少な くなる Wallis パラメータへの $g \sin \theta$ の導入方法を検討した結果，以下の修正 Wallis パラメータ $J_{G}^{* 2}$ を得た.

$$
\left(J_{G}{ }^{* 2}\right)^{1 / 2}=\sqrt{\frac{J_{G}}{\sqrt{g D(1+\sin \theta)^{4}}}}
$$

図 8 に $J_{G}{ }^{2}$ と $Q_{L}{ }^{*}$ 関係を示寸. 図 7 に比ベデータのばらつきが小さく, 本実験範囲における傾斜角の影響を考 慮できたと考えられる.

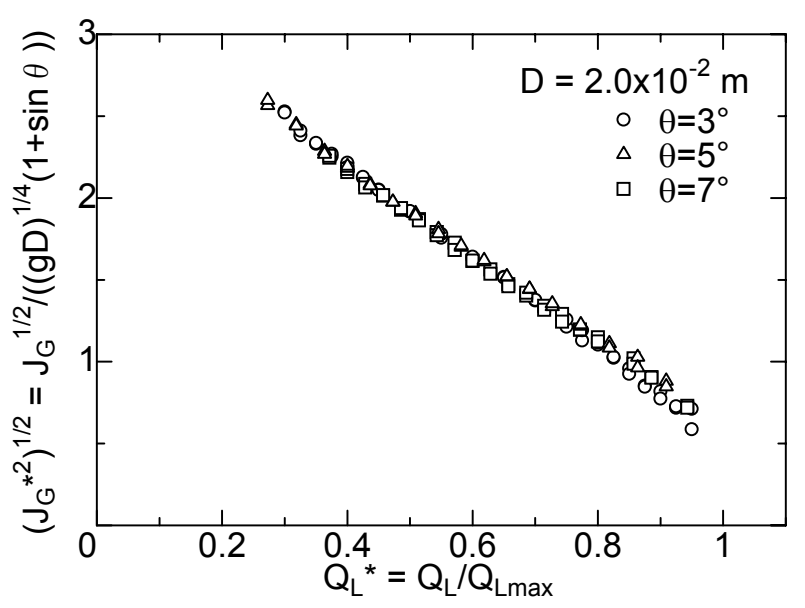

Fig. 8 Effect of $\theta$ on onset of slugging

次に,物性值がスラッギング開始点に及ぼす影響を調べるため, 二種類のグリセリン水溶液を用いて実験した. 液相に働く重力は界面安定化に，浮力は界面の不安定化に寄与寸ると考えられる，そこで，Wallis パラメータの 重力を浮力を差し引いた実効重力とするために，二相の密度差 $\rho_{\mathrm{L}}-\rho_{\mathrm{G}}$ を含めた次式で Wallis パラメータを再定義 した.

$$
\left(J_{G}{ }^{*}\right)^{1 / 2}=\sqrt{\frac{J_{G}}{\sqrt{\frac{\rho_{L}-\rho_{G}}{\rho_{L}} g D(1+\sin \theta)^{4}}}}
$$

$J_{G}{ }^{3}$ と $Q_{L}{ }^{*}$ 関係を図 9 に示寸.グリセリンは水に比べて粘度が大きい（水の約 2.5 倍）にも関わらず，その影 響はほとんど表れていない。

次に管径の影響を検討する. 図 10 に 3 種類の管径に対する実験データを示す. Wallis パラメータは管径を含ん でいるにも関わらず，図 10 では管径によるデータのばらつきが見られる. 特に低 $Q_{L}$ *で管径の影響が大きくなっ ている.これは，メニスカス効果によって決まる滞溜液の界面形状が管径によって異なることが一因と考えられ る. 管径がスラッギング開始点に及ぼす影響を加味するため, 管径 $D=2.0 \times 10^{-2} \mathrm{~m}$ の $J_{G}{ }^{*}$ の各管径での $J_{G}{ }^{*}$ に対 する倍率 $C$ を求めた結果を図 11(a)に示す. $C$ は $D$ および $Q_{L}{ }^{*}$ によって変化するが, $C$ の $Q_{L}$ *依存性はその $D$ 依存 性に比べ小さい, そこで, 本研究では $C$ は $Q_{L}$ *に依存しないと仮定し, 各 $D$ における $C$ の平均值 $\bar{C}$ を用いる. 前述のように $D$ の影響は表面張力に起因寸る滞溜液形状の相違によると考えられる. 滞溜液の形状は，平板上の 液滴形状 ${ }^{(15)}$ と同様に, 表面張力による盛り上がりと重力による変形の相互作用で決定されると考えられる. そこ 


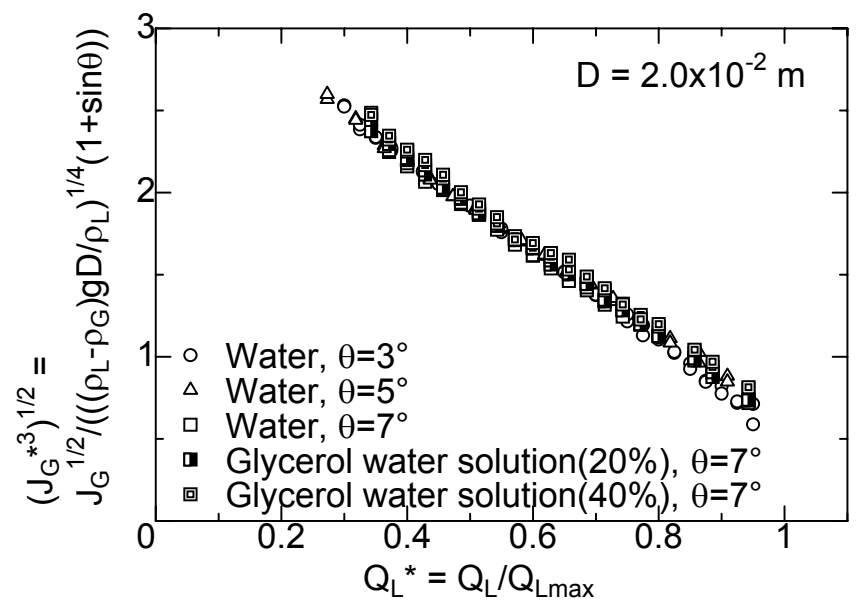

Fig. 9 Effect of physical property of liquid

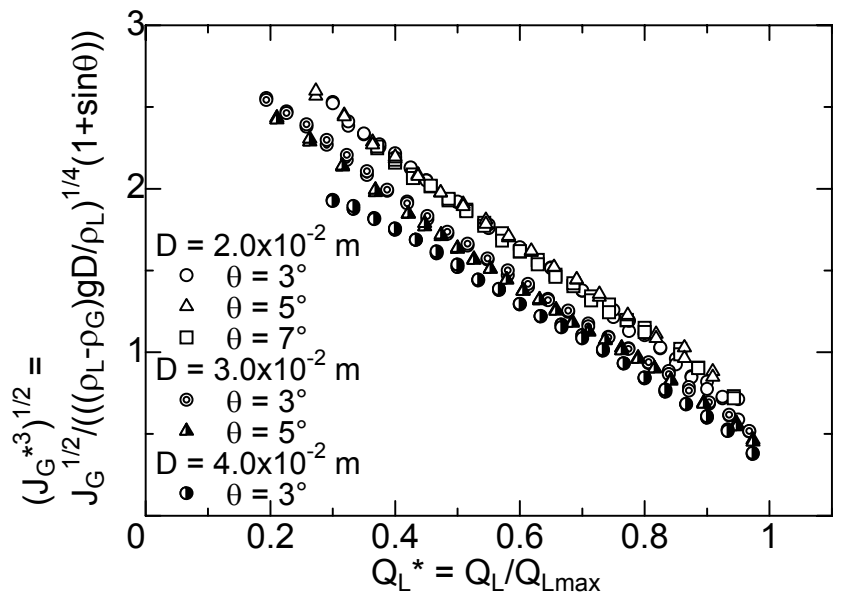

Fig. 10 Effect of $D$ on onset of slugging

で, 図 11(b)に $\theta=3$ ににおける $\bar{C}$ と重力と表面張力の比であるボンド数との関係を示す. $\bar{C}$ と Bo の関係は，本実 験範囲では直線で良く近似できる.

以上より最終的な修正 Wallis パラメータは次式で表される.

$$
\begin{aligned}
& \left(J_{G} *\right)^{1 / 2}=\bar{C} \sqrt{\frac{J_{G}}{\sqrt{f_{g} D}}} \\
& f_{g}=(1+\sin \theta)^{4} \frac{\rho_{L}-\rho_{G}}{\rho_{L}} g \\
& \bar{C}=1.73 \times 10^{-3} B o+0.912
\end{aligned}
$$

傾斜角，物性值，管径を変化させた実験データを修正 Wallis パラメータ $J_{G}{ }^{*}$ で整理し，図 12 に示す。幅広い実 験条件にも関わらず, $J_{G}{ }^{*}$ と $Q_{L} *$ の関係は以下の直線で表せる.

$$
J_{G} *^{1 / 2}=-2.81 Q_{L} *+3.35
$$

$B o$ を用いることにより $D$ に依存しない一本の直線で結果を整理できたことは，Dの影響が主に滞溜液の形状の 違いに現れるという推察を肯定するものであり，本実験よりもさらに大口径の管が使用される石油・天然ガス等 の輸送配管にも式(8) が利用できる可能性があることを示唆している. ただし， D が大きく Bo がある臨界值以上

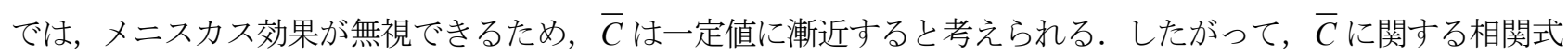
については別途検討する必要がある。 


\section{6. 結 論}

緩傾斜下降管から緩傾斜上昇管に移る V 字部に着目し，V 字管底部に滞溜した液体がその上部を流れる気体に よりスラッギングを開始する条件を調べた。この際，滞溜液相体積と気相体積流束をパラメータとして滞溜液の 流動様式を観察するとともに，スラッギングが発生する臨界気相体積流束を測定した．また，スラグ発生条件の 管傾斜角，管径，液物性依存性を調べた．得られた知見を以下に示寸.

1. V 字部滞溜液の流動様式は静的液溜, 波状液溜, 周期性スラグ, 周期性セミスラグ, 無周期性セミスラグ, 上昇液膜，上昇ペブルに大別でき，スラッギング開始点は，静的液溜もしくは波状液溜から周期性スラグ への遷移に対応する.

2. V 字部でのスラッギング開始条件は，Mishima-Ishii の式よりも Wallis パラメータを用いてより良好に整理 できる．この事実は，V 字部でのスラッギング開始が，フラッディングと同様に界面せん断応力に起因す る界面不安定に伴う流動化と捉えることができることを意味する.

3. Wallis パラメータに傾斜角, 物性值, 管径の影響を加味した修正 Wallis パラメータにより本実験条件範囲 内のスラッギング発生条件を良好に整理できることを確認した。

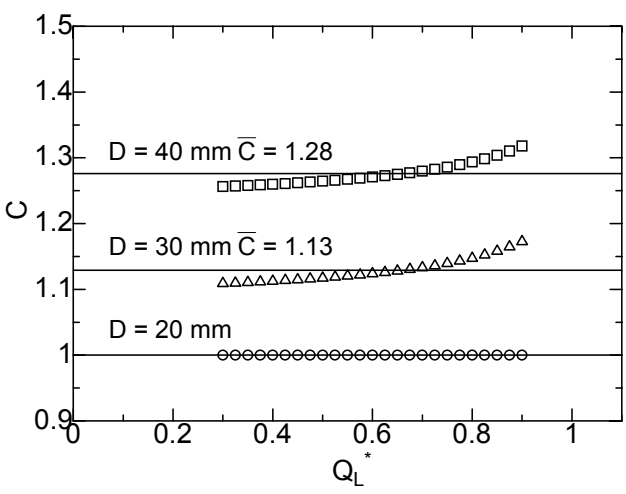

(a) Relationship between $C$ and $Q_{L}{ }^{*}$

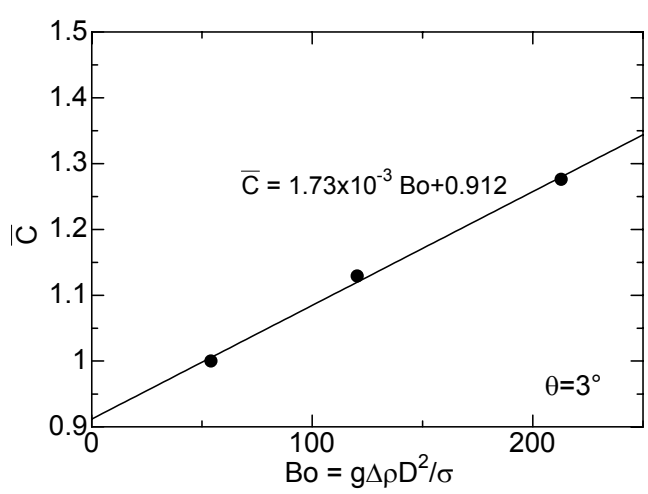

(b) Relationship between $C$ and $B o$

Fig. 11 Multiplier $C$ for $J_{G}{ }^{3}$

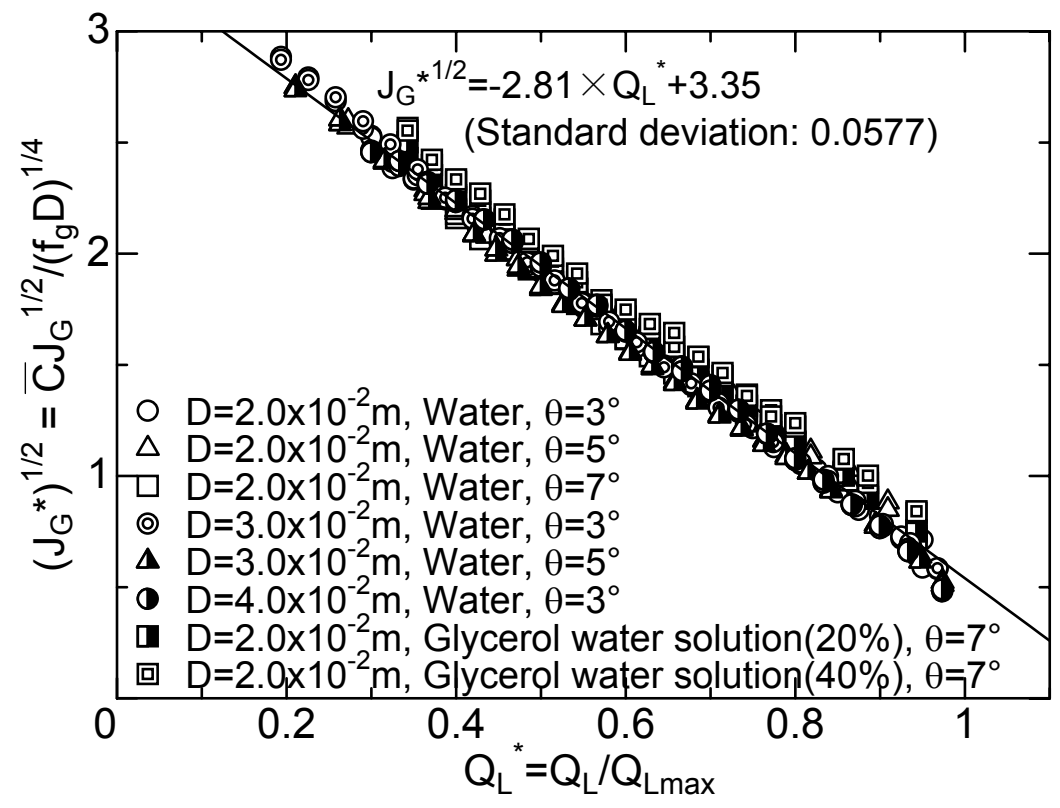

Fig. 12 Relationship between $J_{G}{ }^{*}$ and $Q_{L}{ }^{*}$ 


\section{文 献}

(1) Szilas, A.P., Production and Transport of Oil and Gas (1986), Elsevier, Amsterdam.

(2) De Henau, V. and Raithby, G.D., “A Study on Terrain-Induced Slugging in Two-phase Flow Pipelines”, International Journal of Multiphase Flow, Vol. 21, No. 3 (1995), pp. 365 - 379.

(3) Kordyban, E.S. and Ranov, T., "Mechanism of slug formation in horizontal two-phase flow", ASME Journal of Basic Engineering, Vol. 92 (1970), pp. 857-864.

(4) Wallis, G.B. and Dobson, J.E., "The onset of slugging in horizontal stratified air-water flow", International Journal of Multiphase Flow, Vol. 1 (1973), pp. 173-193.

(5) Mishima, K. and Ishii, M., "Theoretical prediction of onset of horizontal slug flow”, ASME Journal of Fluids Engineering, Vol. 102 (1980), pp. 441-445.

(6) Mishima, K. and Ishii, M., "Measurement and analysis of slug characteristics in multiphase pipelines", 6 th International Conference on Multiphase Production, Cannes. Mechanical Engineering Publications (1993), pp. 179-192.

(7) 細川茂雄, 冨山明男, “下降-上昇傾斜管の V 字部において発生する液体スラグの特性”, 日本機械学会論文集 B 編, Vol. 69, No. 686 (2003), pp.2208-2213.

(8) Zheng, G.., Brill, J.P. and Shoham, O., "Slug flow behavior in a hilly terrain pipeline", Society of Petroleum Engineers, Inc. (1993), pp. 529-541.

(9) Masella, J.M., Tran, Q.H., Ferre, D. and Pauchon, C., "Transient simulation of two-phase Flows in pipes", International Journal of Multiphase Flow, Vol. 24 (1998), pp. 739-755.

(10) Issa, R.I. and Kempf, M.H.W., "Simulation of slug flow in horizontal and nearly horizontal pipes with the two-fluid model", International Journal of Multiphase Flow, Vol. 29 (2003), pp. 69-95.

(11) Bonizzi, M. and Issa, R.I., "On the simulation of three-phase slug flow in nearly horizontal pipes using the multi-fluid model”, International Journal of Multiphase Flow, Vol. 29 (2003), pp. 1719-1747.

(12) Fitremann, J.M., "Methods for calculating two-phase flow in pipes", International Journal of Multiphase Flow, Vol. 3 (1975), pp. 117-122.

(13) 日本原子力学会編, 混相流計測法 (2003), 森北出版.

(14) Wallis, G.B., One-dimensional Two-phase Flow (1969), McGraw Hill, New York.

(15) Sadhal, S.S., Ayyaswamy, P.S. and Chung, J.N., Transport Phenomena with Drops and Bubbles (1997), Springer-Verlag, New York. 